\title{
NOCARDIOSIS AND KIDNEY TRANSPLANTATION: CASE REPORT IN A RECENTLY TRANSPLANTED PATIENT
}

\author{
Relato de caso de Nocardiose em transplante renal recente
}

\begin{abstract}
Gustavo Navarro Betônico', Emerson Nunes Costa2,3, Clayton Santos Souza ${ }^{3}$, Kênio Dias Botelho4,
\end{abstract} Hélio Teixeira², Henrique Vieira Lima ${ }^{2,3}$, Marcus Vinícius de Pádua Netto ${ }^{2,3}$

\begin{abstract}
The patient is a 47-year-old white woman who was on the hemodialysis from 1999 to 2002 , when she received a cadaveric renal transplant (deceased donor). The immediate postoperative immunosupression consisted of oral tacrolimus, predinisone and mycofenolato mofetil (M M F), and her medications at that time of her admission were tacrolimus (5mg 12/12 h), M M F (1000mg 12-12 h), and predinisone (10mg/ day). After 8 weeks, the patient went to the hospital and she was admitted presenting fever (37,9º $)$, cough, malaise and vomiting. The chest radiography revealed a mass in the left superior lobe, which was initially treated with levofloxacin associated to ceftriaxone. There was partial improvement of the cough and total remission of the fever. The patient was discharged after 3 weeks of treatment in stable condition, with negative blood and bronchial cultures. A fter ten days, she returned to the hospital with relapsed symptoms and a subcutaneous purulent collection was detected in her left leg, and the culture of the drained material evidenced a filamentous microorganism, identified as Nocardia sp, later specified as Nocardia asteroides. Treatment with sulfametoxazole-trimetroprin $800 \mathrm{mg}$ t.i.d was initiated, and after five days, the patient was pyretic and treatment was kept for six months.
\end{abstract}

Keywords: Kidney Transplantation; Complication; Infection; Nocardia Infections; Immunosupression; Tacrolimus.

Institutions:

1. Presidente Prudente Medical School - UNOESTE - Presidente Prudente - SP - Brazil

2. Uberlândia Medical School - Uberlândia.

3. Presidente Antonio Carlos Medical School, UNIPAC - Araguari - Minas Gerais - Brazil

4. Catholic University of Brasília-Distrito Federal - Brazil.

\section{Address:}

Marcus Vinícius Pádua Netto

Rua Marques Póvoa, 513 apto 801

CEP: 38400431 - Uberlândia - Minas Gerais - Brasil

Telephone: 553432363079

E-mail:marcus@nanet.com.br

Recebido em: 15.03.2006

Aceito em: 31.05.2006

\section{INTRODUCTION}

A successful renal transplantation depends on a relationship between attaining a sufficient immunossupression to avoid the graft rejection and maintaining a sufficient level of immune competence to protect the recipient from infections, which are caused in transplant recipients by several and of ten unusual agents. ${ }^{1}$ Recently, reports on infections caused by Nocardia sp, an aerobic actinomycete are becoming more common, probably related to the more powerful immunosuppressive regimens. ${ }^{1}$ It is estimated that 500 to 1000 new cases of nocardiosis occur in the US each year, with $13 \%$ occurring in organ transplant recipients. ${ }^{2}$

\section{CASE REPORT}

The patient is a 47-year-old white woman who was on hemodialysis from 1999 to 2002, when she received a cadaveric renal transplant. The immediate postoperative immunosuppression consisted of oral tacrolimus, predinisone and mycofenolato mofetil (M M F), and her medications at that time were tacrolimus (5mg 12/12, M M F $1000 \mathrm{mg}$ $12 / 12$, prednisone $10 \mathrm{mg} /$ day, and furosemide $40 \mathrm{mg} /$ day. It was required her admission in the hospital two months after the transplant, when she presented fever $\left(37.9^{\circ} \mathrm{C}\right)$, cough, malaise and vomiting. A Iso, she reported oliguria and her physical examination revealed no signs of dehydration, normal blood pressure and no fever.

The cardiac examination was unremarkable, with no extra sounds or murmurs. Lung examination was unspecific with bilateral ronchi, 
neck with no adenopathy and extremities without edema. A llograft in the right lower quadrant of her abdomen was nontender. At the date of the admittance in the laboratory, it was presented as follows: leukocytosis, without anemia or diminished platelet counting, serum lactate dehydrogenase $1173 \mathrm{U} \mathrm{I} / \mathrm{dL}$, creatinine $1,6 \mathrm{mg} / \mathrm{dL}$ and BUN $230 \mathrm{mg} / \mathrm{dl}$, glucose $184 \mathrm{mg} / \mathrm{dL}$. Chest radiography revealed a left superior lobe mass, which was initially treated with levofloxacin associated to ceftriaxone after collection of blood culture samples (Fig 1). A flexible bronchoscopy was performed; no gross endobronchial masses but purulent secretion were seen. B rushing and washing were sent to citopathology and microbiology.

A fter antibiotic treatment, the cough was partially solved, the fever
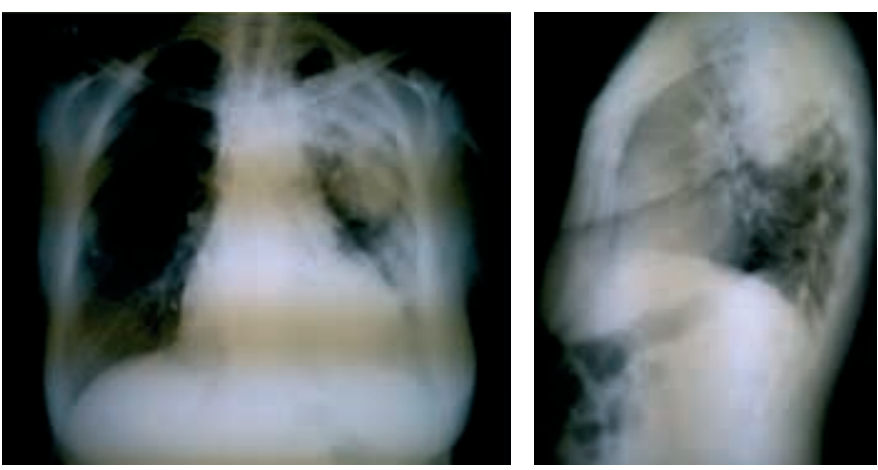

disappeared and as the creatinine still increased, she underwent an allograft biopsy that revealed acute tubular necrosis associated to tacrolimus toxicity. She was discharged in stable condition after 3 weeks of treatment, with negative blood and bronchial cutures. Ten days later, she returned to the hospital with relapsed symptoms and persistent radiograph image, that time reveal ling a pul monary cavity (Fig 2), confirmed by chest CT scan (fig 3). A nother series of blood and bronchial cultures were performed and remained negative. A fter one week, a subcutaneous purulent collection was detected in the left leg and the culture of the draining material evidenced a filamentous microorganism, identified as Nocardia sp, later specified as N ocardia asteroides. Treatment with sulfametoxazole-
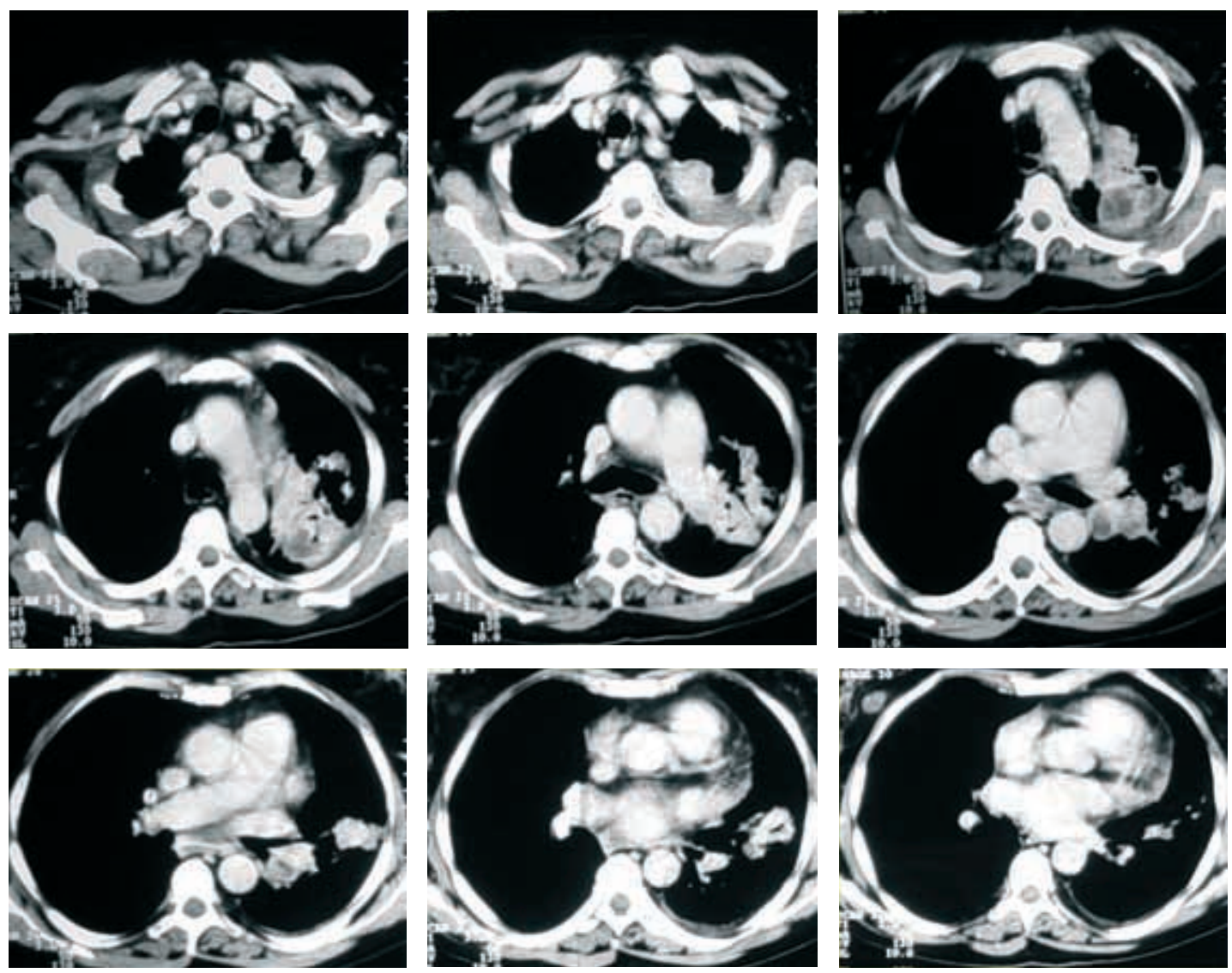
trimetroprin $800 \mathrm{mg}$ t.i.d was initiated and after five days the patient was apyretic and treatment was maintained by 6 months.

Her immunossupressive regime was changed to cyclosporine $150 \mathrm{mg}$ b.i.d and blood levels were adjusted for the late post-transplant period.

\section{DISCUSSION}

Nocardiosis is a localized or disseminated infection caused by soil-borne aerobic, gram-positive, variably acid-fast, filamentous bacteria. Nocardia species are actinomycetes found in soil, including sand, domestic dust and even swimming pools. ${ }^{3}$

Infections caused by Nocardia sp can be present in a variety of clinical forms, including skin lesions, ${ }^{3}$ pulmonary lesions, cerebral abscess and ocular lesions occurring isolated or combined. 4,5,6,7 Infection can occur through inhalation but some reports skin inoculation. ${ }^{8}$ Nocardia asteroides is the most frequent human pathogen, accounting for $80 \%$ to $90 \%$ of infections, and it is associated to pulmonary, cutaneous, and disseminated disease. ${ }^{8,9}$

Routine microbiological tests can identify other species such as Nocardia. brasiliensis and Nocardia. otitidiscaviarium. Recently, development of more specific tests turned possible the differentiation of two subgroups of $\mathrm{N}$. asteroides, which are considered distinct species: N. farcinica and N. nova.

In the case here reported, the first pulmonary infection could be related to Nocardia sp, but as previously reported, culture samples containing Nocardia species can be prematurely discharged, since they have a slow grow th rate. ${ }^{10,11}$ A nother cause of persistent negative cultures, specially in bronchial brushings, is the growth of other microorganisms than Nocardia, which hide the appearance of Nocardia colonies. ${ }^{12}$

A pproximately one-third of the cultured materials become positive except for abscess or fistula material when isolation is more frequent. This fact comes together with our findings, because the diagnostic of N ocardia infection was only made after the metastatic leg abscess appeared and the cultured material was positive.
Pulmonary nocardiosis has an incidence of 2 to $5 \%$ in kidney transplant patients, and it can present acute, sub acute and chronic forms, as nodules, cavities, and alveolar infiltration, including resembling a typical bacterial pneumonia with or without pleural effusion.13 O ur patient initially had pulmonary presentation and good response to the used antibiotics turned correct the diagnostic of usual pneumonia.

$\mathrm{M}$ ajor risk factors for nocardiosis include lympho-reticular neoplasm, chronic obstructive pulmonary disease, systemic immunossupression and others disorders associated with cellular immune dysfunction, immunoglobulin deficiencies and leukocytes defects. ${ }^{14}$

Additional risk factors for nocardiosis in renal transplant patients include the amount of rejections, age $<10$ or $>40$ years, high-dose versus low-dose of prednisone, cadaveric versus living releted kidney transplant, granulocytopenia, and uremia. ${ }^{15}$ O ur patient had ${ }^{4}$ of these risk factors: she was over 40 years, received a cadaveric renal transplant, and she was on an increased immunossupressive regimen.

Recently, despite the prophylaxis with sulfametoxazoletrimetroprin, incidence of Nocardia infections in transplant patients seems to be increasing.

Some reports suggest that more aggressive immunossupression regimens, mainly the combination of tacrolimus and $M M F$ are responsible by the increasing incidence of the disease. ${ }^{8} \mathrm{~A}$ lthough the exact mechanism is not known, it has been demonstraded that tacrolimus interacts with M M F to produce increasing levels of mycophenolic acid, the active metabolite of M M F.15 Patient was receiving tacrolimus and $M M F$, and such combination must be considered a factor in the development of her nocardial infection.

The disease has variable incidence, and it decreased after the prophylaxis with sulfametoxazol-trimetroprin was routinely initiated, although in some related cases, trimethoprimsulfamethoxazole given as prophylaxis against Pneumonystis carinii pneumonia and/or urinary tract infection was not effective for nocardia in patients on tacrolimus regimen..$^{8-12}$

\section{RESUMO}

Introdução: Paciente de 47 anos, branca, mantida em terapia renal substitutiva de 1999 até 2002, quando recebeu transplante renal de doador cadáver. A terapia imunossupressora inicial constava de tacrolimus, prednisona e micofenolato mofetil ( M M F). No momento da internação, as doses utilizadas eram respectivamente: $5 \mathrm{mg}$ 12/12h de tracolimus, 1000mg 12/12h de M M F, 10mg/dia de prednisona e $40 \mathrm{mg} / \mathrm{dia}$ de furosemida. A pós oito semanas, a paciente procurou o hospital e foi internada com quadro de febre (37,9ํㄷ), tosse, malestar e vômitos. Foi solicitado RX de tórax, que revelou uma massa no lobo superior esquerdo, inicialmente tratado com levofloxacin associado a ceftriaxone. Houve mel hora parcial do quadro de tosse, com remissão total da febre. A paciente recebeu alta após três semanas de tratamento em boas condições, com todas as culturas negativas. Passados dez dias, a paciente retornou ao hospital com os mesmos sintomas anteriores, tendo sido encontrada coleção purulenta subcutânea na perna esquerda, que foi drenada, e o material coletado foi enviado para exame. Foi evidenciado um microorganismo filamentoso identificado como Nocardia sp, posteriormente especificado como Nocardia asteroi des. Foi iniciado tratamento com sulfametoxazol-trimetroprin 800mg 12/12h, e após cinco dias, a paciente já se mostrava afebril e o tratamento foi mantido por seis meses.

Descritores: Transplante R enal; Infecção; Nocardiose; Imunossupressão, Tacrolimus. 


\section{REFERENCES}

1. Fishman J, Rubin R. Infection in Organ-Transplant Recipients. N Engl J Med. 1998Jun 11;338:1741-51.

2. Wilson JP, Turner HR, Kirchner KA, Chapman SW. Nocardial infections in renal transplant recipients. Medicine. 1989 Jan;68(1):38-57. Review.

3. McNeil MM, Brown JM. The medically important aerobic actinomycetes: epidemiology and microbiology. Clin Microbiol Rev. 1994 Jul;7(3):357-417. Review.

4. Agarwal R, Ayyagari A, Prasad KN, Nag VL, Sharma RK. Primary subcutaneous Nocardia asteroides infection in a renal allograft recipient. Mycopathologia 1999 Dec;148(3):113-5.

5. Magee CC, Halligan RD, Milford EL, Sayegh MH: Nocardial infection in a renal transplant recipient on tacrolimus and mycophenolate mofetil. Clin Nephrol. 1999 Jul;52(1):44-6.

6. Tan SY, Tan LH, Teo SM, Thiruventhiran T, Kamarulzaman A, Hoh HB: Disseminated nocardiosis with bilateral intraocular involvement in a renal allograft patient. Transplant Proc. 2000 Dec;32(7):1965-6.

7. Palomares M, Martinez T, Pastor J, Osuna A, Bravo JA, Alvarez G, Asensio C: Cerebral abscess caused by Nocardia asteroids in renal transplant recipient. Nephrol Dial Transplant. 1999 Dec;14(12):2950-2.
8. Wong KM, Chak WL, Chan YH, Choi KS, Chau KF, Lee KC, Li CS. Subcutaneous nodules attributed to nocardiosis in a renal transplant recipient on tacrolimus therapy. Am J Nephrol. 2000 Mar-Apr;20(2):138-41.

9. Reddy SS, Holley JL. Nocardiosis in a recently transplanted renal patient. Clin Nephrol. 1998 Aug;50(2):123-7.

10. Lerner PI, Mandell GL, Bennett JE, Dolin R. Mendell, Nocardia species. Principle and practice of infectious diseases. 4th ed. 1995 Vol. 2. New York: Churchill Livingstone.:2273-80.

11. Kursat S, Ok E, Zeitnoglu A, Tokat Y, Saydam G, Cirit M, et al. Nocardiosis in renal transplant patients. Nephron. 1997 Jan;75(3):370-1.

12. Gutierrez H, Salgado O, Garcia R, Henriquez C, Herrera J, Rodriguez-Iturbe B. Nocardiosis in renal transplant patients. Transplant Proc. 1994 Feb;26(1):341-2.

13. Maccario M, Tortorano AM, Ponticelli C. Subcutaneous nodules and pneumonia in a kidney transplant recipient. Nephrol Dial Transplant. 1998 Mar;13(3):796-8.

14. Zucker K, Rosen A, Tsaroucha A, Roth D, D. Roth, G. Ciancio, et al. Augmentation of mycophenolate mofetil pharmacokinetics in renal transplant patients receiving prograf and cellcept in combination therapy. Transplant Proc. 1997 Feb 29;(1):334-36.

15. Boiron P, Locci R, Goodfellow M, Gumaa SA, Isik K, Kim B, et al. Nocardia, nocardiosis and mycetoma. Med Mycol. 1998;36 Suppl 1:26-37. 